\title{
FACTORS INFLUENCING INTENT TO ADOPT BIG DATA ANALYTICS IN MALAYSIAN GOVERNMENT AGENCIES
}

\author{
Mad Khir Johari Abdullah Sani* \\ Faculty of Information Management, UiTM Puncak Perdana Campus \\ Muhamad Khairulnizam Zaini \\ Faculty of Information Management, UiTM Puncak Perdana Campus
}

Noor Zaidi Sahid

Faculty of Information Management, UiTM Puncak Perdana Campus

Norshila Shaifuddin

Faculty of Information Management, UiTM Puncak Perdana Campus

Tamara Adriani Salim

Faculty of Humanities, Department of Library and Information Science, Universitas Indonesia

Noorazah Md. Noor

Malaysian Administrative Modernisation and Management Planning Unit (MAMPU), Prime Minister's Department, Putrajaya

\begin{abstract}
In Big Data Analytics (BDA), many government agencies directly raised their ICT expenditure in their effort to understand the attitude of the users towards new technologies. This research is intended to analyze factors affecting IT practitioners' behavioral intentions in adopting (BDA) using a combination of multiple technology acceptance models. The synergistic three IS theory strengths: (1) Task Technology Fit (TTF), (2) Unified Technology Acceptance and Utilization Theory (UTAUT), and the (3) Initial Trust Model (ITM). The concept was validated in Malaysian government agencies, one of the highly dependent BDA promoters and initiators. 186 respondents in the Information Management departments of public agencies were recruited as part of the rigorous methodology to gather rich data. Partial least squares were analyzed by the structural models (PLS). The two key factors determine behavioral intention to adopt BDA in government agencies. Firstly, the assumption that the technology is going to produce great results raises the expectation of performance. Technological fit was the second determinant factor. Initial trust, on the other hand, was found to be adversely related to the BDA intention. Implicitly, the proposed model would be useful to IT officers in public agencies in making investment choices and designing non-adopter-friendly outreach strategies because they have more barriers to acceptance than adopters and lead adopters in the reward ladder. All public agencies will benefit from the findings of this study in gaining awareness of BDA application and fostering psychological empowerment of employees to adopt this revolutionary approach. The article outlines how
\end{abstract}

\footnotetext{
* Corresponding author: Senior lecturer, Faculty of Information Management, UiTM Puncak Perdana Campus, 40150 Shah Alam, Selangor, Malaysia; Tel: 603-79622102; Email: madkhirjohari@uitm.edu.my
} 
dynamic TTF, UTAUT and ITM are for researchers to integrate in their emerging decision support framework for the study of new technology adoption.

Keywords: Big Data Analytics, Public agencies, Library and Information Management, Adoption Model

Received: 24 July 2020

Accepted: 3 June 2021

https://doi.org/10.33736/ijbs.4304.2021

\section{INTRODUCTION AND BACKGROUND OF THE STUDY}

\subsection{Introduction}

Literally, BDA is the process of evaluating data which are large in size and variety (Big Data) to find patterns hidden, unknown correlations and other useful information as coined by Sivarajah et al. (2017). Furthermore, Galetto (2018) defined BDA is "the method of examining large data sets containing a range of data types to uncover hidden patterns, unknown correlations, market trends, customer preferences, and other useful information". In an analysis of data growth, Desjardins (2017), predicted by 2025, 463 exabytes of data are expected to be generated globally each day, and 90 percent of these data are unstructured. Alcácera and Cruz-Machado (2019) who studied the growth of the BD trend, mentioned that the managing of large data besides high frequency formats and forms was also closely related. Khan et al. (2014) continued the concern that within the rapidly rising data medium is unstructured data. Likewise, in its BDA portal, Malaysian Administrative Modernisation and Management Planning Unit (MAMPU, 2014) claimed the growth of emerging technologies can generate incentives to improve the quality of their services for industries and government agencies by providing innovative services never before existed.

Several scholars have concentrated on BDA adoption in governmental entities (Kim et al., 2020; Löfgren \& Webster, 2020; Pencheva et al., 2020; Nantais, 2019) and explored the value of BD, especially in private companies (i.e. Hasan et al., 2020; Ballantyne \& Stewart, 2019; Mikalef et al., 2018; Shahbaz et al., 2019; Shahbaz et al., 2020). Munné (2016) claimed that the public sector can greatly increase efficiency by deliberately using BD. BD can address a wide-ranging variety in public sector issues like improved efficiency (MAMPU, 2014; Kubina et al., 2015), integrity (OECD , 2018) and wellbeing (Wang \& Moriarty, 2018). Different online methods also offer viable solutions to the recovery of reduced resources in public administrative organizations (Kennedy et al., 2015). As of now, rapid data growth in the use of BD in the private sector was given attention (Hasan et al., 2020).

It is therefore crucial to remain aware of how BD roles are adopted in the public sector and how organizations can gain advantage from BD. While BD and its role in the government agencies were further diligently considered (see for instance, Yunus, 2018; Pencheva et al., 2020; Munné, 2016), gaining insights into the intention to use BD should also help plan and leverage currently unused data sets in the public sector. Therefore, the core research question for this research is "what factors affect the intention to use Big Data Analytics in Malaysian government agencies".

In Malaysia, various agencies are beginning to realize the importance of adopting data analytics in making smart decisions (Paramasivam, 2016). Among them is the provision of infrastructure and 
info structure to support public data analytics by MAMPU (MAMPU, 2014). A broader perspective has been adopted Raja Mohd Ali et al. (2016) who argued that MAMPU is a body responsible for promoting the modernization and digital transformation of the Malaysian government through BDA. Furthermore, World Bank Group (2017) analyzed related policies and strategies, which are also being developed by MAMPU in conducting public data analytics through four pilot applications, namely: "Price Control - Ministry of Domestic Trade, Cooperatives and Consumerism (KPDNKK); Sentiment Analysis - MAMPU; Crime Prevention - Royal Malaysian Police (PDRM) and Infectious Disease Prediction - Ministry of Health Malaysia (MOH)”.

\subsection{Statement of the Problem}

MAMPU had conducted pilot applications of BDA involving four government agencies, however the progress of BDA adoption in all government agencies is still low. In fact, the use of BDA needs to be extended to all levels of the ministries to be used as information to formulate effective programs (MAMPU, 2014) based on the "Public Administration Transformation Circulars Bill. 1 of 2017 entitled Implementation of Public Sector Public Data Analysis (DRSA) by the Modernization Unit Administration and Management of Malaysia (MAMPU), Prime Minister's Department". Given the government's serious attention to big data, Raja Mohd Ali et al. (2016) highlighted scarcity of information in terms of public sector preparatory for BD. A research by Paramasivam (2016) showed that BDA programs foster creativity in public service to simultaneously meet the necessities of the strategic reform programme for a digital government, but only $44 \%$ have started to prepare for a digital strategy and think of their capabilities. By integrating strategies and BDA adoption factors, it assisted the government to implement decisions more effectively (Bahari, 2016) and new products and services from the database (Vitari \& Raguseo, 2020), which led to critical national transformation agenda. Hence, the framework to be developed will reveal what factors influencing BDA adoption should government agencies assess. Abbasi et al. (2016) in a BD editorial called for a research exploratory agenda on behavioral factors affecting the use of BDA in organizations. An organization needs to consider the factors that influence proposed usage of BDA so that they can take effective steps to implement it.

\section{LITERATURE REVIEW}

\subsection{Big Data Analytics}

BDA provides strategies and technologies for gathering, storing, transferring, analyzing and displaying vast volumes of structured and unstructured data (Erevelles et al., 2016). Others (see Elragal \& Klischewski, 2017; MAMPU, 2016; Al-Shiakhli, 2019) emphasized the BDA as the use of profound learning techniques on large datasets, including data collection, analysis, prescriptive modelling, etc., as modern business intelligence practice. Some other way of thinking of BDA is the method of analysing data sets so as, with the help of advanced systems and software, to draw conclusions about the information they produced (Stedman, 2017). Data science methods and technologies in the industrial sectors are commonly used to allow organizations to make informed decisions; and enable science experts and researchers to validate or falsify science models, theories and hypotheses. 


\subsection{BDA Studies in Malaysia}

Malaysia has prioritized data science as a national plan and is well equipped to leap over other countries by incorporating it into a program that leads to more evidence-driven decision-making organizations (MAMPU, 2016). In this regard, a pilot project aimed at improving public sector IT climate landscape was declared by the government of Malaysia to introduce the Analitis Data Raya Sektor Awam (ADRSA) involving multiple ministries (Galetto, 2018). This program encourages creativity in government services while meeting the essential needs of the national digital government modernization agenda. Incorporating data from various sources helps the government to implement decisions more efficiently, creates new database products and services, shares information and results, leading to a critical national transformation agenda. The Ministry of Communications and Multimedia (MCMC) has led the implementation of BDA in Malaysia, in collaboration with MAMPU and Malaysia Development Corporation (MDeC), and established BDA for Malaysia (MAMPU, 2016).

The Microsoft study in the 2016 Asia Data Culture survey revealed that $85 \%$ of policymakers in Malaysia believed it is essential for business to make use of data, but only $44 \%$ have started to prepare for a digital strategy. The Microsoft survey comprises 940 small and large business leaders in 12 Asian markets. 45 of them came from Malaysia alone (Paramasivam, 2016). Most of those from Malaysia agreed with the cultural advantages of BDA, but there are obstacles to be overcome. Using BDA, Malaysia Airport Berhad, coupled with the right communication strategies, found the total number of positive items in customer feedback management was calculated at $72 \mathrm{~K}$ compared to the negative $27 \mathrm{~K}$ items, which is significant in providing better passenger experience through new customer engagement channels such as social media (The Multimedia Development Corporation (MdeC), 2016). Furthermore, Lagisatu.com asserts that the benefit of BDA adoption is the delivery of timely insights from the vast amount of data. Similarly, Paramasivam (2016) found approximately $88 \%$ of Malaysian businesses confidently reported BDA will determine their success in the industry. Clearly, the industry has begun to understand the importance of IT graduates and skilled manpower (talent capabilities) in the field of data analysis. MAMPU (2016) claimed if organizations understand and collect the data in connection with their trade or business, they can analyze and gain value significantly from it as well as are able to estimate trends and to anticipate market growth.

\subsection{Assessing the Public Sector to Adopt Big Data Analytics}

Longo and McNutt (2018) discussed how BD could change the public agencies data analytics strategy. Data analytics is the evaluation of solutions for public agencies issues. The traditional data analysis is characterized by conventional quantitative analysis methods used in the 70s and 80s (Longo \& McNutt, 2018). However, BD, supported by the modern-day technology, can enhance public agencies. Günther et al. (2017) and MAMPU (2016) concluded by highlighting some of the issues associated with adopting BD, one notably that government has to build enough capacity for an appropriate application data analytics in government bodies. This can be accomplished by providing training to the public employees (OECD, 2018). Similarly, Schintler and Kulkarni (2014) found other potentials or threats in the public service leveraging BD. The benefit includes provision of useful information, and detailed, precise and prompt decision-making data (Pencheva et al., 2020; World Bank Group, 2017; MAMPU, 2016). However, using BD comes with some notable challenges. The fact that BD are usually skewed, too complex (Sivarajah et al., 
2017), and tend to be missing some relevant information; are in brevity, BD tend to be biased in some cases (McFarland \& McFarland, 2015). A set of BD might have lost its contextual value when they are being processed, reshuffled, repurposed and reinterpreted going through the phase of being supplied to the end users (Schintler \& Kulkarni, 2014).

As far as the theoretical and practical data usage of government departments, it provides a solid foundation for BDA (Sivarajah et al., 2017). BDA tools must therefore be incorporated into the study of public agencies. One of the challenges identified by Giest (2017) and Ingrams (2019) is limited institutional support for BD management and capacity within the government. As highlighted by MAMPU (2016), when the government has low level of analytical capacity, they would have to source for additional stakeholders with the right skill sets. Furthermore, UNESCO (2017) opined that the issue of capacity can be solved by training government workers in data analytics or simplifying the ambiguities involved in analyzing BD for policy decision making. Walker and Brown (2019) agreed that using BD in policymaking should be at the problem identification stage, where data serves as an evidence to gauge the severity of a social problem. BD should also serve as the basis for policy makers in setting their priorities; should be considered at the root cause analysis stage for social problems (Sivarajah et al., 2017) and factors influencing intent to adopt need to be explored systematically as done by different scholars, as shown in Table 1.

Table 1: Summary of Relevant Research on Factors Influencing Intent to Adopt BDA

\begin{tabular}{|c|c|c|}
\hline Researcher & Description & Findings (Factors Influencing) \\
\hline $\begin{array}{l}\text { Shahbaz et al. } \\
(2019)\end{array}$ & $\begin{array}{l}\text { Using a survey questionnaire, } 224 \\
\text { representative AMOS v21 responses were } \\
\text { examined to evaluate the BDA } \\
\text { implementation process for health } \\
\text { institutions in order to investigate } \\
\text { elements relevant to behavioral intent } \\
\text { using a framework for application } \\
\text { recognition models and role management. }\end{array}$ & $\begin{array}{l}\text { The Task-Technology Adoption } \\
\text { Paradigm leads significantly to } \\
\text { strengthening behavioral expectations } \\
\text { for the use of BDA in health care. }\end{array}$ \\
\hline $\begin{array}{l}\text { Brock and Khan } \\
(2017)\end{array}$ & $\begin{array}{l}\text { Determined the level of recognition with } \\
\text { and variations in renowned models such as } \\
\text { TAM. Via the synchronization with OLC, } \\
\text { the study examined the reasons for } \\
\text { adopting BDA. }\end{array}$ & $\begin{array}{l}\text { The study showed a } 44 \% \text { difference } \\
\text { between the consumer behavior of } \\
\text { large data and other models in model } 4 \\
\text { (built using the OLC and TAM } \\
\text { frameworks). }\end{array}$ \\
\hline $\begin{array}{l}\text { Wahab et al. } \\
(2018)\end{array}$ & $\begin{array}{l}\text { Investigated the main determinants that } \\
\text { impact on BDA targets in the warehouse } \\
\text { industry in Malaysia. The TEC / OM } \\
\text { paradigm (TOE) was introduced as the } \\
\text { core principle in promoting the logical } \\
\text { structure. }\end{array}$ & $\begin{array}{l}\text { The findings indicated five reasons } \\
\text { (relative advantage: technology } \\
\text { infrastructure, absorptive capability, } \\
\text { industry competition and government } \\
\text { support) that may have a huge impact } \\
\text { on BDA acceptance potential in the } \\
\text { warehouse sector. }\end{array}$ \\
\hline Lai et al. (2018) & $\begin{array}{l}\text { This paper discussed the factors } \\
\text { influencing the decision of businesses to } \\
\text { incorporate BDA in their everyday } \\
\text { business. In this study, potential variables }\end{array}$ & $\begin{array}{l}\text { The perceived advantages and support } \\
\text { of the senior management would } \\
\text { significantly influence the decision. } \\
\text { Environmental influences including } \\
\text { market penetration, legislation and SC }\end{array}$ \\
\hline
\end{tabular}




\begin{tabular}{ll}
\hline & $\begin{array}{l}\text { were specifically listed in four categories: } \\
\text { technology, organization, climate and SC. }\end{array}$ \\
\hline $\begin{array}{l}\text { Maroufkhani et al. } \\
(2020)\end{array}$ & $\begin{array}{l}\text { The purpose of this paper is to have an } \\
\text { exceptional and integrated model for BDA } \\
\text { adoption among SMEs by integrating a } \\
\text { TOE model from a resource-based } \\
\text { perspective. }\end{array}$ \\
\hline Schüll and Maslan & $\begin{array}{l}\text { To understand and integrate the sense of } \\
\text { decision-making process with } \\
\text { perspectives from the hierarchical } \\
\text { capability theory, the technology and the } \\
\text { climate paradigm (TOE Paradigm) are } \\
\text { adopted and also used to describe the } \\
\text { technology acceptance process. }\end{array}$
\end{tabular}

accessibility will substantially moderate the causal relation between the operator and the acceptance intention.

The results had shown that technology and organization, as part of the BDA adoption, are the most important determinants for SMEs.

The most important influences, which have close ties to management support, are expertise and internal data use. In channelling BDA savings, this gives skills growth high priority. The expected level of BDA competition and the potential for competitive difficulties (if BDA is not adopted) may not be a shock.

\begin{tabular}{ll}
\hline $\begin{array}{l}\text { Cabrera-Sánchez } \\
\text { and Villarejo- }\end{array}$ & $\begin{array}{l}\text { The research tailored the Unified } \\
\text { Ramos (2019). }\end{array}$ \\
& $\begin{array}{l}\text { Technology Theory of Adoption and Use } \\
\text { of Technology Models (UTAUT) to the }\end{array}$ \\
& BDA context by introducing two \\
variables: resistance to use and perceived \\
risk.
\end{tabular}

The findings showed that four dimensions dictate the behavioral intent to use BDA in companies: (1) performance expectancy, (2) social influence, (3) facilitating conditions, and (4) reluctance to use.

The findings suggested that exposure to appropriate data form the backbone of the system and will become the most effective facilitator in the process of acceptance, whilst the organization has the most significant technological ability for employees. It had also been found that the rating of enablers from Interpretive Structural Model and (ISM) Analytical Network Process (ANP) is high.

Sam and Chatwin Based on the Technology-Organization(2019). Environment (TOE) framework, the study highlighted the potential factors influencing Chinese organizational Big Data adoption.

The findings indicated that organizational participants really ought to plan their (1) technical, (2) organizational, and (3) environmental assets for the purposes of BDA.

Bolonne and The three perspectives of the TechnologyWijewardene Organization-Environment Paradigm (2020) (TOE) together with the Technology Acceptance Model (TAM) were used as underpinning structures to explore the impact on user attitudes that would ultimately influence the intention to implement BDA.

The findings pointed out that variables, namely: (1) technological factors, (2) environmental context, (3) perceived ease of use, and (4) perceived usefulness, have a positive impact on the users' attitudes towards BDA adoption. 


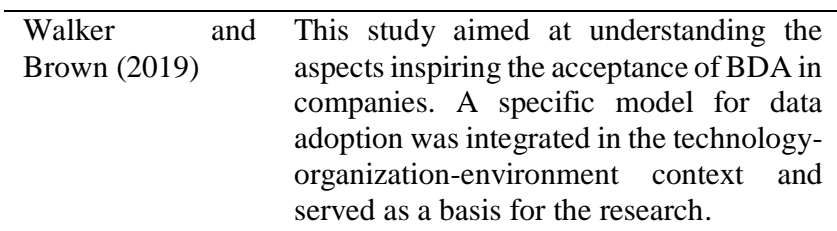

Verma and

Chaurasia (2019)
To analyse the variables that impact organizations' adoption of big data analytics (adopters and non-adopters).
The BDA acceptance process had been influenced by five technical influences, which were (1) fairly favorable, (2) stable, (3) trialable, and (4) data accuracy, and (5) relative advantage. The BDA implementation process was affected by four organizational considerations, which included: (1) high-level managerial assistance, (2) experience in human resources, (3) the integration between enterprise and IT, and (4) organizational aspect. The BDA acceptance process has been verified by five environmental variables: (1) economic competition, (2) protection of records, (3) seller assistance, (4) IT, and (5) regulatory requirements. The capacity of organizations to move from intent to BDA to actual execution has been verified by two-fold factors: (1) tolerances of ambiguity, and (2) changes in perspective.

Technology, organization and environment affect the adoption of big data analytics by companies. The big data analytics adopters have an important influence on their relative advantage, complexity, compatibility, top management support, technical readiness, organizational data environment and competitive pressure. In the meantime, perceived profit, sophistication and competitive risks affect the non-adopters of Big Data Analytics

\subsection{Designing the Conceptual Model}

The main influences in this work were the Initial Trust Model (ITM) (McKnight \& Chervany, 2006), the Unified Theory of Acceptance and Use of Technology (UTAUT) (Venkatesh et al., 2003), as well as the Task Technology Fit (TTF) (Goodhue \& Thompson, 1995) model, which were used in predicting the behavioral intentions towards BDA (Shahbaz et al., 2019). As for every emerging technology, BDA performs a significant position in longevity of innovation and efficiency (Rialti et al., 2019). The survey instrument and analysis model was developed to test the relation between the concepts of the ITM model, the TTF model, and the UTAUT. Since BDA facilitates the protecting of government agencies' transaction data, IT professionals' confidence in BDA technology is a crucial factor in adopting this technology. The confidence is a core topic in BDA, as demonstrated by Schneider et al. (2018). It can help to improve confidence in BDA by explaining "blackbox" models, demonstrated models' transferability, and structural rigidity in 
terms of data adjustments to quality or contents. The model in this study consists of the TTF model and the initial assurance model used by the TTF model to assess BDA system adoption in combination with the original trusted model to analyze the IT professionals' attitudes in modifying the trusted model.

The UTAUT system plays a minor role in the study paradigm because of the presumed existence of BDA technology. The calculation of the UTAUT platform adoption rate is not an effective technique. The purpose to perform is one of the acceptance variables of this equation, selected as the dependent variable. Of the four UTAUT principles (Venkatesh et al., 2003), only a performance expectation concept was used to test the hypothesis. The assumption of BDA as a measure of the profitability of the enterprise contributed to improved corporate success. The success appraisal component analyzed employee efficiency, operational performance, and customer satisfaction (Vitari \& Raguseo, 2020). Perceptions of effort and social impact have disrupted the study because the respondents have no realistic experience of this application. Moreover, the TTF theory asserts that the system will be used by the user if the technical features meet task requirements, based on Goodhue and Thompson's (1995) theory. It is also possible to adopt this technology if the user finds technology as useful, simple and innovative, but if it does not meet the requirements, its required tasks and does not improve job performance, it may not be adopted as discovered by Zhuang et al. (2017). The user should therefore not only have to believe that such innovation is efficient and helpful but also that the technology features will conform to the necessary tasks. The study hypotheses were classified into seven major categories in this proposed model:

\subsubsection{Task-Technology Fit (TTF) Model}

In TTF, a technology that enables a person to accomplish his or her tasks (Spies et al., 2020) is defined and crucially influenced by the interplay between task characteristics and technology functionality (D'Ambra et al., 2013). Data quality, data location, access authorisations, data compatibility, ease of use / training, timeless manufacturing, system reliability, user information system relationships are the typical dimensions taken into account when measuring fit, as defined by Goodhue and Thompson (1995). The task characteristics and technology characteristics decide TTF, which contributes to the information system being adopted and used (Goodhue \& Thompson, 1995). Several researchers have employed the TTF model. Said (2015) used TTF to examine the performance effect determinants of knowledge management system. Liebenberg et al. (2018) used the updated TTF model to analyze the variables impacting the insurance industry adoption of mobile commerce (Lee et al., 2007). Klopping and McKinney (2004) used a hybrid approach that merged TTF and technology acceptance models to test e-commerce adoption.

Successful implementation of the information system fits the definition of the purpose for which the innovation is used and on an acceptable linkage between technology and its objective. Goodhue and Thompson (1995) explained TTF decomposition explores the user's information system specifications, which ultimately have an effect on individual results. The TTF model reflects a significant positive impact for smartphones in the digital library environment of tasks and technologies as revealed by Vongjaturapat's (2018) study. Technology means the integration of different supporting activities (i.e. computers and applications) for these tasks. Previous research by Bibri and Krogstie (2017) defined specific role dimensions (e.g. storage, data aggregation, analysis, data management and surveillance) applied to a variety of technological aspects that met the needs of individuals in BDA technology. Task and technologies also have a huge effect on the 
TTF capacity to predict success of users hailing from digital textbook service study (Rai \& Selnes, 2019). If the individual demands for success were not met; creative information technology and program would be inopportune (Zhou et al., 2010). Recognizing the BDA program TFF is also essential, as it contributes to public organizations implementing the program.

In recent research, TTF has analyzed the efficiency of the user's technology and group-level decision-making process to assess the performance of various organizational settings of the information system (i.e., massive Open Online courses [MOOCs] (Heidari et al., 2018); BDA and the digital library (Omotayo \& Haliru, 2020). Accordingly, we conclude that the successful implementation of BDA by public agencies depends substantially on balancing technology with the user role requirements, which previous researchers have not examined. In their survey, Rai and Selnes (2019) conceptualized TTF and even the integration of technology with a number of related tasks that help in achieving the development goal in an organization.

\subsubsection{Unified Theory of Acceptance and Use of Technology (UTAUT)}

Cao and Niu (2019) conducted a survey, which explained the determinant factors affecting users to take Alipay as one of payment platforms in China. This research includes the theory and UTAUT on context awareness. Context, ubiquity, social impact, performance expectation, expected effort, perceived risk and the Alipay user acceptance are all constructs. Efficiency and effort expectancy act as a mediation construct for Alipay user adoption between context and ubiquity. The context has a good impact on user adoption through mediation performance and effort expectations as a result of path analysis, while ubiquity has influence too.

Yang et al. (2019) also integrated UTAUT and Connected Classroom Climate (CCC) in their research. The findings showed that actions, social impact and CCC substantially influence the Cloud classroom adoption. In their field of research, Kurt and Tingöy (2017) aimed at investigating to what degree students accept and use virtual or online school learning environments. The findings showed that behavioral intent of the performance expectancy variables is significantly affected.

Ngampornchai and Adams (2016) carried out a study aimed at finding out how many Thai students can accept e-learning and how they respond to e-learning. The research variables were adapted from the UTAUT and Moore and Benbasat's (1991) models. The findings indicated a very positive relationship between performance and effort expectancy. Social influence also had a positive relationship. This is evidenced by the students' statements that their parents are happy to have their child enrolled in an online course. In addition, e-learning acceptance is also related to the school year. Senior students are likely to be more responsive to e-learning, even if only a few of them take online classes. The relevance of this study is also its use of the UTAUT model, but there is still a shortcoming as it included only one item to measure performance expectancy influence variables.

\subsubsection{Initial Trust Model (ITM)}

A person's desire to meet his/her needs without having previous experience or accuracy and relevant information implies the meaning of initial trust (Kim \& Prabhakar, 2004; Gao \& Waechter, 2017). The simple, scalable, and expected advantages, such as service quality, are linked to initial confidence creation (Koufaris \& Hampton-Sosa, 2004). When users have little to no history in accepting new technologies, the initial trust plays a significant role (Shahbaz et al., 2019). 
Consequently, these users seek insight which ensures reliable data and analysis (KPMG, 2016). The position of initial e-commerce trust is correlated with areas such as online shopping (Jibril et al., 2019) and mobile banking services (Lin et al., 2020) that have been thoroughly researched in this field. Mahfuz et al. (2016) employed the ITM to create a model that describes mobile banking adoption to customers in Bangladesh.

Researchers have highlighted diverse initial trusts influence factors that could be described in two major categories. The first category relates to individual personality traits such as the propensity to trust that represents the individual's natural inner potential. In the preceding analysis, a good predictor for initial trust is trust propensity (Kaabachi et al., 2019). The personal inclination directly affects initial trust, which is supported by Heidari et al. (2018) findings. The second category is structural assurance. The trust is focused on the favorable outcomes of other parties' future actions (Zhou, 2013) and on their ability to be vulnerable. Trust typically consists of three convictions: ability, integrity and generosity (Zhou, 2013). Confidentiality has been shown to have profound consequences for the use by users in a range of services, including Online Health Consultation Services (Gong et al., 2019), online banking (Kaabachi et al., 2019), social networking (Abbas Naqvi et al., 2020), and public e-services (Alabdallat, 2020).

As data science emerges over the past few years, trust in the field of BDA becomes more important. For example, Shahbaz et al. (2019) have demonstrated the positive impact of trust and strength in the information system on BDA conduct intentions. The trust in technology, reviewed by Wayne (2018), has a positive effect on intended use of BDA while Debussche et al. (2019) stressed "the important aspect of" confidence "in the context of BD is confidence because stakeholders believe in honesty in the process of gathering, treating and analyzing BD." It is from an analytical point of view of Woolley (2019) that analyses complied with ethical standards, met with the information requirements, and maintained public trust in the mechanism of decision taking.

\subsection{Conceptual Model of the Research}

The principal influences for the study have been the initial trust model (McKnight \& Chervany, 2006), the TTF model (Goodhue \& Thompson, 1995) and the standard principle of technology acceptance and usage (UTAUT), used for forecasting technology adoption (Uddin et al., 2020). The conceptual model for this study was chosen from Oliveira et al. (2014) analysis, which used the composite theoretical paradigm of the initial confidence paradigm, the TTF model, and a coherent theory of UTAUT to forecast acceptability of mobile banking among final consumers (Oliveira et al., 2014).

As with other new technologies, BDA and intelligent contracts are viewed as useful tools to government agencies (Mithas et al., 2012). The survey methodology and analysis model have been developed to determine the relationships between the principles of the confidence model, the taskapplication model and the coherent system acceptability and usage principle (UTAUT). Since BDA is responsible for protecting transaction details and the intelligent contract is used for the execution of public services transactions, the user's confidence in the BDA technology is a key element in the acceptance of such technologies in government agencies (MAMPU, 2016). Given that BDA affects the security paradigm of the users, this transition involves a shift in the mindset of users, as public agencies were historically responsible for building trust; now the trust is cryptographic due to the existence of BDA and the elimination of intermediaries (OECD, 2018). Of the same cause, 
the model of the study consists of a task-technology match model, and an original confidential model under which the TTF model and ITM were used to measure the effectiveness of BDA technology as a financial method to analyze consumer behaviour towards modifying the confidential trend.

The UTAUT architecture plays a minor role in the research paradigm since BDA technology is viewed. Among the four UTAUT principles (Venkatesh et al., 2003) the theory was checked only through a principle of performance expectation. Prior work showed that anticipation of results and its performance outcomes are the determining factors of behavioral intent. For BDA, this could lead people to believe for employees to use conventional working practices when they trust that BDA technologies and applications will not help them operate better or perform more efficiently. Expectations of commitment and social impact have disrupted the study because the respondents have no realistic experience of this application. It has also been observed that promoting circumstances directly influences the adoption of this definition (Venkatesh et al., 2003). The study dimension of the model was therefore not used.

Hypothesis 1

Structural assurance provides assurance that the BDA could be carried out in a protected and secure way that protects users from data loss or exposure to privacy by maintaining protective and technological structures (Abouelmehdi et al., 2018). Trust is related to structural assurance as found from McCole's et al. (2019) study in a pure e-service context (online betting). Higher levels of systemic assurance will help BDA users conquer fear of revealing sensitive data broadly and raise their level of confidence in such data. The summaries of the International Telecommunication Union (ITU) (2018) reports on "BD, machine learning, consumer protection and privacy", that the large quantity of data held and transmitted by BD players creates risks of violation of data security, and thus of privacy and trust for consumers. Rights to privacy can be protected in different ways by using technologies to enhance privacy (PETs).

\section{H1: Structural assurances in the BDA have a positive effect on the initial trust.}

Hypothesis 2

Through previous interpersonal trust study, the tendency to trust has indicated faith and trust through actions. Alarcon et al. (2016) had used a revamped version of the dilemma duties of the inmate to discuss the relationship of loyalty and trust both in common and new ways. The confidence tendency was calculated using a revised Mayer and Davis (1999) confidence scale and perceived trustworthiness Fiduciary scale edition. Heidari et al. (2018) found the personal propensity to trust directly affects the initial trust among innovators familiar with the blockchain technology accounting for 222 subjects. Researchers have highlighted diverse initial trusts influence factors that could be described in two major categories. The first category relates to individual personality traits such as the propensity to trust that represents the individual's natural inner potential. In the preceding analysis, a good predictor for initial trust is trust propensity (Kaabachi et al., 2019). The personal inclination directly affects initial trust, which is supported by Heidari et al. (2018) findings. The second category is structural assurance.

\section{H2: The personal propensity to trust in the BDA technology has a positive effect on the initial trust.}




\section{Hypothesis 3}

The level of trust begins at zero before an individual undertakes interactions and relationships (Lewicki \& Bunker, 1996). Falahat et al. (2019) argued that individuals are in trust to decide if online exploration or transaction is necessary. Initial trust is the initial step when there is a lack of immediate information, credibility and knowledge of BDA (Sbaffi \& Rowley, 2017; Falahat et al., 2019). Initial trust is the introductory stage. Sbaffi and Rowley (2017) also proposed an initial trust model that individuals will use to decide whether to explore or deal online especially with BD. Initial trust and perceived utility as values, according to the principle of reasoned action (TRA), can influence behavioral motives ( $\mathrm{Yu} \&$ Lee, 2019). Initial trust may also help to mitigate perceived vulnerability and danger and encourage deliberate use. It was observed that perceived utility was a major factor impacting initial usage and persistent usage (Venkatesh \& Davis, 2000). Many studies had documented the influence of initial trust in behavioral motives and their presumed utility (Okello \& Gilson, 2015; Talwar et al., 2020). Possible IT professionals find better decisions on analytics or technology that could dictate whether or not they may use BDA in the near term. Initial trust is willingness to rely on things, which makes individuals believe the risks and uncertainties of trading (Smithson, 2018). In order to resolve risk perceptions of IT professionals and persuade IT professionals to negotiate with them, government agencies therefore should have appropriate trust in this first level, which is notably crucial for the performance of BDA.

\section{H3: Initial trust has a positive impact on the user's intention in accepting the BDA technology in government agencies.}

Hypothesis 4

Technologies are characterized as "devices that people use to accomplish their tasks." "Software applies to computing programs in the sense of Information System (hardware, Technology, software and support services to users (trainings, help lines, etc.)) is provided to enable users to carry out their tasks" (Goodhue \& Thompson, 1995, p. 216). The TTF model recognizes the importance of adjusting to the specifications imposed by individual needs the capabilities and qualities of technology (Vongjaturapat, 2018) and consistently Schindler et al. (2017) critical review of the literature when they found the characteristics of technology (accessibility, response time) can influence technology use and user preferences. Goodhue and Thompson (1995) proposed that user reviews would not be arbitrary, but rather represent the realistic characteristics of the relevant system and facilities. Goodhue and Thompson's (1995) interpretation of task-technology disregarded the interdependence of tasks.

This study has therefore customized the TTF to analyze Compatibility between the roles of IT practitioners and BDA, as the model would be used to assess the use of BDA as clarified from a task perspective. It is expected that in the situation that they perform their tasks with minimum costs, optimum productivity and performance, the IT practitioners are more favorable to use BDA (Mikalef et al., 2019). The adoption model for Task-Technology Fit (TTF) indicates that the customer should approve a new system when it is effective enough to perform routine tasks (O'Connor et al., 2020). Acceptance of the current information structure thus depends entirely on the everyday routine activities of the staff in the organization. The task features and technology features decide the task-technological fit, which contributes to the information system being adopted and used (Goodhue \& Thompson, 1995). TTF model was employed by several researchers. Wang and Lin (2019) found TTF is significantly influenced by BDA's technology features in 
mobile cloud healthcare. Likewise, as evidenced by Shahbaz et al. (2019) technology features have major effects on TTF 's ability to provide BDA in healthcare.

\section{H4: The technological features of the BDA have a positive effect on the task-technology fit.}

Hypothesis 5

TTF into the degree of technology defined by Goodhue and Thompson (1995). Whether or not BDA technology will help users to carry out their job, the task-to-tech fitness needs to be observed at the time of application (Laugesen \& Hassanein 2017; Wu \& Chen 2017; Tam \& Oliveira, 2016). The TTF into this study: how users utilize the BDA features to carry out government service tasks. BDA-related task features are generated on a very large scale and many multinationals process and analyze them so that insights can be found, and organizations can be improved (Lehrer et al., 2018). The task features have a positive impact on the TTF from different studies as confirmed by (eg. in BDA setting (Wang \& Lin, 2019; Shahbaz et al. 2019); smartphones setting (Vongjaturapat, 2018; Bere, 2018); cloud computing setting (Khidzir et al., 2017; Yoo \& Kim, 2019) blockchain setting (Heidari et al., 2018). An important task feature of BDA is advanced analytics with complex applications, such as predictive modelling, statistical algorithms and high-performance analysis systems. This study presents the following hypothesis:

\section{H5: The task features of BDA have a positive impact on the task-technology fit.}

Hypothesis 6

The efficient use of an IT system depends on the role to be performed and whether the job and the systems are sufficient. As explained in Goodhue and Thompson (1995), TTF decomposition examines the information system requirements of the user, which ultimately affects each individual's performance. The integration of a range of support activities to fulfil these tasks is the technology (i.e. computers, applications, etc.). Latif et al. (2018) finding contribute to a variety of technological criteria that meet the individual's needs (e.g. non-routines, coexistence, data access, and quantitative data analytics). Task and technology have a huge effect on TTF capability to predict users' performance from various perspectives (Rai \& Selnes, 2019). Innovative software and system technology would be unsuccessful if the performance criteria for a given task were not met (Shahbaz et al., 2019). Moreover, Shahbaz et al. (2019) discovered that the TTF corresponds significantly to improving the behavioral intentions of the BDA system in the healthcare industry. Interestingly, TTF proves to be significantly associated to the adoption of cloud computing in Khidzir et al. (2017) research. It is also essential to achieve the BDA program task-technology match because it helps government agencies implement the appropriate program and strategy.

\section{H6: The task-technology fit has a positive effect on users' behavioral intent in adopting $B D A$ in government agencies.}

\section{Hypothesis 7}

Performance expectancy sheds light on understanding the importance of the emerging technologies and is one of the most prominent behavioral intentions. The estimation of results in the unified acceptance and use of technology theory (UTAUT) tests a person's confidence that the system is useful and advantageous to the user (Venkatesh et al., 2003). Oliveira et al. (2014) considered the predicted performance in the UTAUT as the expected performance in the technology adoption model and consideration it as a critical part of the proposal to the technology acceptor (Oliveira et 
al., 2014). The statistically direct relationship in the context of performance expectancy and behaviour BDA intention is confirmed by several studies (Cabrera-Sánchez \& Villarejo-Ramos, 2019; Chao, 2019; Queiroz \& Farias, 2019).

\section{H7: The performance expectancy will positively affect the user's behavioral intent in accepting the $\mathrm{BDA}$ in government agencies.}

Figure 1 shows the framework of the research based on the above discussion.

Figure 1: Research Framework

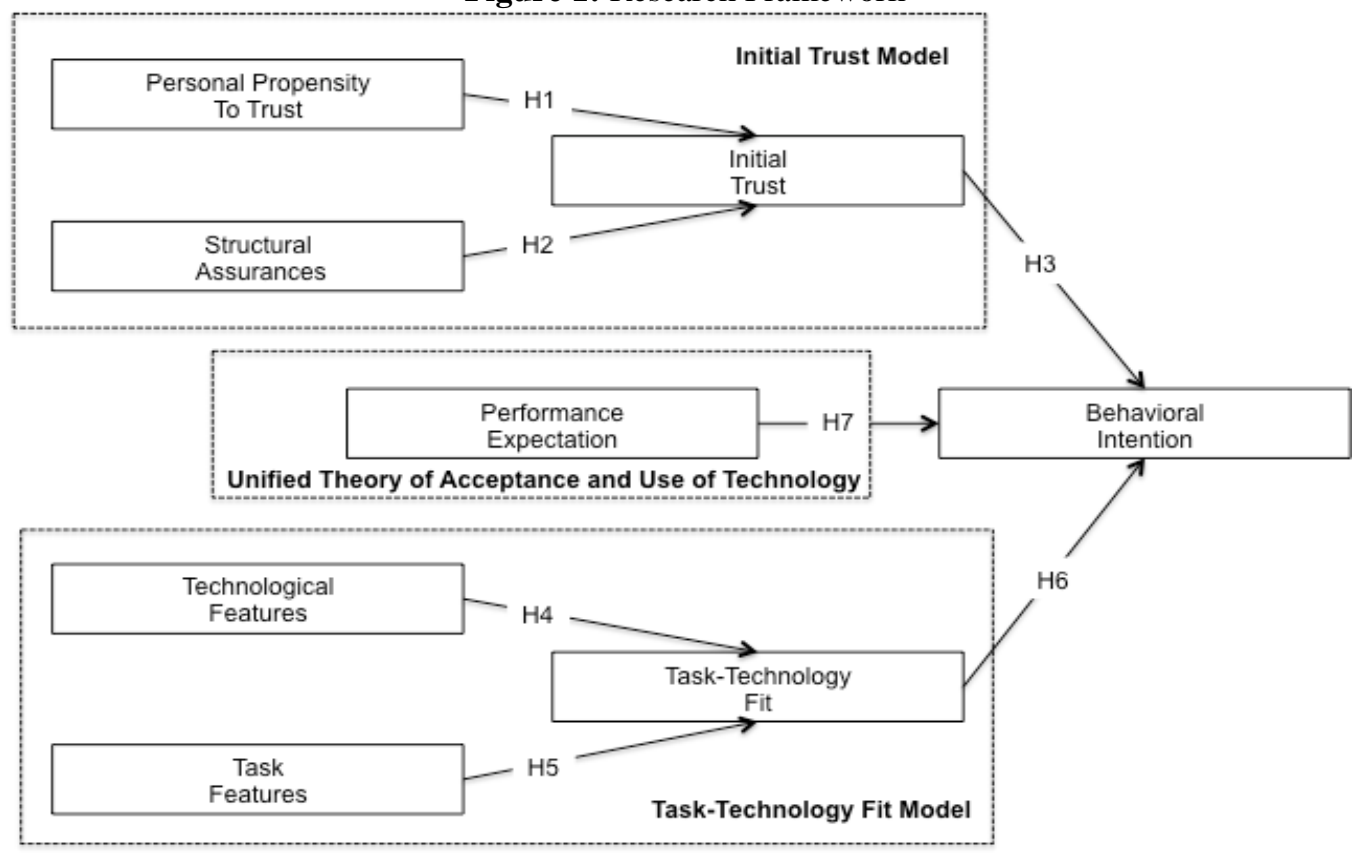

\section{METHODOLOGY}

\subsection{Data Collection and Analysis}

A questionnaire was conceived and divided into two parts. In the first section, the eight constructs presented in the research model were measured and adopted by using 33 items (see Table 2). The eight mechanisms have been classified as (1) Behavioral Intent, (2) Initial Trust, (3) Performance Expectation, (4) Personal Propensity, (5) Structural Assurance, (6) Task Features, (7) Technology Fit, and (8) Technological Features. Various items were measured against each construct. A 5point Likert scale for the answers was implemented to quantify the constructs. The Likert scale comprised of 5 answers from "strongly disagree" (1) to "strongly agree" (5). Part two of the questionnaire included the respondents' demographic information. It gathers fundamental 
information on the characteristics of the respondent such as age, gender and work experiences (year).

We piloted the questionnaire to improve its quality before the actual survey. This pilot study aimed primarily to validate empirically the reliability of the instrument by checking that all observed variables are accurate and reliable (Hair et al., 2010). Reliability was tested for every construct based on the alpha of Cronbach for which the threshold was 0.7 (Hair et al., 2010). 35 IT professionals responded in the pilot study. The reliability ranged from 0.731 for PR to 0.901 for fulfilment, based on the Cronbach Alpha score. The authors found that the alpha values from Cronbach reached 0.7 for all variables. The questionnaire was reviewed to be accurate and functional after the correct reliability was verified for all measured constructs.

Using a cross sectional survey, empirical data were collected. Two hundred IT professionals from Information Management departments government agencies were selected randomly. Having the experience, having heard, and the practice of ICT for daily tasks as well as BDA were acceptable for all IT professionals involved. All respondents had been notified of the research and all of them are volunteers and had been assured that their answers are kept confidential, that their confidentiality is maintained and that their responses are used only for the purpose of the study. The participants completed the questionnaire in 15-20 minutes. Given the information of the BDA respondents, a total of 200 questionnaires form were obtained and screened. Fourteen insufficient answers were subsequently discarded leaving 186 valid structured data review questionnaires

\subsection{Data Analysis}

The Partial Least Square Modeling of Structural Equations is one of the best software for verifying structured data on structural equations modeling (SEM). In the earliest phases of theory construction, when the theoretical model and its measurement were not yet completed, the PLS retrieval is particularly effective in data analyses (Hair et al., 2006). The PLS model examines besides identifies (1) the measurement model and (2) the conceptual design for its reliability and validity. In this study, the PLS regression was used to analyse and confirm the envisaged model and the relationship between hypothesized structures. The 186 samples were 128, that is $68.8 \%$ were males and $31.2 \%$ were females. There were 70 respondents in the first $21-29$-years range, i.e., $37.6 \%$ per cent of the sample and the second 30-39-years group had 60 respondents, i.e. $32.3 \%$ of the sample. Respondents from the 40-49-years group constituted 53 or $28.5 \%$ of the sample and 3 or $1.6 \%$ of the sample are 50 years old and older.

Table 2: Research Constructs

\begin{tabular}{|c|c|c|}
\hline Variables & Number of Items & Reference \\
\hline $\begin{array}{l}\text { Behavioral } \\
\text { Intention }\end{array}$ & $\begin{array}{l}\text { 1. The intention to manage organisation activities using the } \\
\text { BDA-based platforms } \\
\text { 2. Interested in knowing more about the BDA-based } \\
\text { platforms } \\
\text { 3. Making changes to organisation decisions using the } \\
\text { BDA-based platforms } \\
\text { 4. The review of organisation decisions and benefits using } \\
\text { the potentials in the BDA-based platforms } \\
\text { 5. I intend to use BDA in the future }\end{array}$ & $\begin{array}{l}\text { Queiroz and } \\
\text { Wamba (2019) } \\
\text { and adjusted to } \\
\text { the context. }\end{array}$ \\
\hline
\end{tabular}




\begin{tabular}{|c|c|c|}
\hline Initial Trust & $\begin{array}{l}\text { 1. I believe that BDA is trustworthy } \\
\text { 2. I have trust in BDA } \\
\text { 3. I do not doubt the honesty of big data } \\
\text { 4. I feel assured that legal and technological structures } \\
\text { adequately protect me from problems on BDA. }\end{array}$ & $\begin{array}{l}\text { Heidari et al. } \\
\text { (2018) and } \\
\text { adjusted to the } \\
\text { context }\end{array}$ \\
\hline $\begin{array}{l}\text { Performance } \\
\text { Expectation }\end{array}$ & $\begin{array}{l}\text { 1. I find BDA useful in my daily taks } \\
\text { 2. Using BDA increases my chances of completing tasks } \\
\text { that are important to me } \\
\text { 3. Optimizing organisational operations } \\
\text { 4. Achievement of organisational benefits }\end{array}$ & $\begin{array}{l}\text { Alalwan et al. } \\
\text { (2017). }\end{array}$ \\
\hline Personal Propensity & $\begin{array}{l}\text { 1. The tendency to use the capabilities of BDA } \\
\text { technology } \\
\text { 2. The tendency to use data analytic } \\
\text { 3. I would definitely consider taking the BDA for decision } \\
\text { making } \\
\text { 4. My tendency to trust BDA is high. }\end{array}$ & $\begin{array}{l}\text { Heidari et al. } \\
\text { (2018) and } \\
\text { adjusted to the } \\
\text { context }\end{array}$ \\
\hline $\begin{array}{l}\text { Structural } \\
\text { Assurances }\end{array}$ & $\begin{array}{l}\text { 1. Having the backing of legal statutes and processes } \\
\text { makes me feel secure in using analytics products } \\
\text { 2. Product guarantees make it feel all right to use analytics } \\
\text { software. } \\
\text { 3. I feel okay using analytics products because vendor } \\
\text { protections back them. } \\
\text { 4. Favorable-to-consumer legal structures help me } \\
\text { feel safe working with analytics products }\end{array}$ & $\begin{array}{l}\text { Heidari et al. } \\
\text { (2018) and } \\
\text { adjusted to the } \\
\text { context }\end{array}$ \\
\hline Task Features & $\begin{array}{l}\text { 1. BDA is used to discover hidden patterns for my } \\
\text { service } \\
\text { 2. BDA can provide insights into data analysis and } \\
\text { decision-making platform. } \\
\text { 3. BDA processing features involve the collection and } \\
\text { organization of raw data to produce meaning. } \\
\text { 4. BDA tools offer a variety of analytics packages and } \\
\text { modules to give my options. }\end{array}$ & $\begin{array}{l}\text { Adapted from } \\
\text { Adair (2019) and } \\
\text { adjusted to the } \\
\text { context }\end{array}$ \\
\hline $\begin{array}{l}\text { Task-Technology } \\
\text { Fit }\end{array}$ & $\begin{array}{l}\text { 1. BDA is appropriate for, and tailored to, faster, better } \\
\text { decision making in my organisastion } \\
\text { 2. BDA is suitable for, and tailored to, cost reduction in } \\
\text { my organisation } \\
\text { 3. BDA is fit for, and tailored to, new products and } \\
\text { services in my organisation } \\
\text { 4. BDA is appropriate for, and tailored to, more efficient } \\
\text { operations in my organisation }\end{array}$ & $\begin{array}{l}\text { Bere (2018) and } \\
\text { adjusted to the } \\
\text { context }\end{array}$ \\
\hline $\begin{array}{l}\text { Technological } \\
\text { Features }\end{array}$ & $\begin{array}{l}\text { 1. Our organization is well computerized with LAN and } \\
\text { WAN } \\
\text { 2. Providing real-time (instant) services } \\
\text { 3. Providing secure service } \\
\text { 4. Our existing systems are flexible }\end{array}$ & $\begin{array}{l}\text { Heidari et al. } \\
\text { (2018) and } \\
\text { adjusted to the } \\
\text { context }\end{array}$ \\
\hline Demographic & $\begin{array}{ll}\text { 1. } & \text { Working experience } \\
\text { 2. Gender } \\
\text { 3. }\end{array}$ & \\
\hline
\end{tabular}

The following clusters of working experience were considered. In the group of government departments, 62 respondents or $33.3 \%$ had 6 - 10 years of experience. There were 38 participants 
with 6-10 years' experience in the class period. It resulted in a total of 38, i.e. $20.4 \%$, followed by 36 respondents, each with 1 to 5 years of working experience. $7.5 \%$ or 14 of those who replied had 21 to 25 years of working experience, while $6.5 \%(n=12)$ had been working for 26 to 30 years. Finally, $1.1 \%$ or 2 respondents were those with more than 30 years of work experience.

\subsubsection{Measurement Model Analysis}

\subsubsection{Reliability}

Two values can be used to access the model's reliability; the alpha coefficient of Cronbach over 0.6 in the interitem accuracy evaluation and composite reliability where the value ranged from 0.7 or higher is considered appropriate (Fornell \& Larcker, 1981). In this analysis, as shown in Table 3 , the composite reliability of the model calculation values ranged from 0.698-0.930 for the Alpha value of Cronbach and from 0.816-0.966 for composite reliability, as shown in Table 3 . The values indicate that it is sufficient to regularly calculate the tools. The model's effects are seen in Figure 2.

\subsubsection{Validity}

The ultimate focus of the validity test is to assess fitness and to split it into measures of convergent validity and discriminant validity. Convergent validity can be measured by looking at the outcomes of the factor loading, composite reliability and even the average variance extracted (AVE) calculation model (Hair et al., 2014). Table 3 indicates that, as Hair et al. (2014) reported, the factor loading of each item (0.70-0.90) in the build surpassed the supported value of 0.5 (Hair et al., (2014). Table 3 also demonstrates the validity of the model by displaying the composite reliability value of the model above 0.90 , which exceeds the suggested value of 0.7 (Hair et al., 2010). The average extracted variance (AVE) values of the model also surpass the predicted value of 0.5 (Hair et al., 2014) with a range of 0.751-0.889, which represents the total amount of variance in the latent build products. Thus, the result is appropriate for this paradigm for convergent validity.

It is determined by examining the point that the confident interval value of the HTMT statistic should not contain the value of 1 for an overall construct mixture and also by calculating the HTMT value below 0.90 (Hair et al., 2014) as seen in Table 3. It indicates that the HTMT value of the entire construct is less than 0.10 , suggesting marginal discriminant validity for the model. It can be inferred on the basis of the above discussion that all eight variables determining intention to adopt DBA constructs are valid for evaluating individual constructs based on their factor estimates and statistical evidence. Overall, the discriminatory validity of this assessment model may be recognized and confirms the discriminatory validity of the constructs. 
Table 3: Construct Reliability, Validity and Loadings Result

\begin{tabular}{|c|c|c|c|c|c|c|c|}
\hline \multirow[b]{2}{*}{ Variables } & \multirow{2}{*}{$\begin{array}{l}\text { Item } \\
\text { Number } \\
\text { of Items }\end{array}$} & \multicolumn{2}{|c|}{ Convergent Validity } & \multicolumn{2}{|c|}{$\begin{array}{c}\text { Internal Consistency } \\
\text { Reliability }\end{array}$} & \multicolumn{2}{|c|}{ Discriminant Validity } \\
\hline & & $\begin{array}{c}\text { Item } \\
\text { loading }\end{array}$ & $\begin{array}{c}\text { Average } \\
\text { Variance } \\
\text { Extracted } \\
\text { (AVE) }\end{array}$ & $\begin{array}{c}\text { Alpha } \\
\text { value } \\
\alpha\end{array}$ & $\begin{array}{c}\text { Composite } \\
\text { Reliability } \\
\text { (CR) }\end{array}$ & HTMT & VIF \\
\hline & & $>0.70$ & $>0.70$ & $>0.80$ & $>0.90$ & $\begin{array}{c}\text { Confidence } \\
\text { Interval } \\
\text { Does Not } \\
\text { Include } 1\end{array}$ & $<5.00$ \\
\hline $\begin{array}{l}\text { Behavioral } \\
\text { Intention }\end{array}$ & 5 & $0.851-0.938$ & 0.821 & 0.945 & 0.958 & Yes & \\
\hline Initial Trust & 4 & $0.882-0.976$ & 0.889 & 0.958 & 0.970 & Yes & 1.132 \\
\hline $\begin{array}{l}\text { Performance } \\
\text { Expectation }\end{array}$ & 4 & $0.763-0.925$ & 0.751 & 0.889 & 0.923 & Yes & 1.252 \\
\hline $\begin{array}{l}\text { Personal } \\
\text { Propensity }\end{array}$ & 4 & $0.726-0.972$ & 0.837 & 0.933 & 0.953 & Yes & 1.078 \\
\hline $\begin{array}{l}\text { Structural } \\
\text { Assurances }\end{array}$ & 4 & $0.910-0.955$ & 0.876 & 0.953 & 0.966 & Yes & 1.078 \\
\hline Task Features & 4 & $0.850-0.889$ & 0.762 & 0.900 & 0.928 & Yes & 1.236 \\
\hline $\begin{array}{l}\text { Task- } \\
\text { Technology } \\
\text { Fit }\end{array}$ & 4 & $0.803-0.938$ & 0.783 & 0.908 & 0.935 & Yes & 1.223 \\
\hline $\begin{array}{l}\text { Technological } \\
\text { Features }\end{array}$ & 4 & $0.891-0.957$ & 0.859 & 0.945 & 0.961 & Yes & 1.236 \\
\hline
\end{tabular}

Table adapted from Hair et al. (2014)

*AVE: Average Variance Extracted; HTMT: Heterotrait-Monotrait Ratio; VIF: Collinearity Statistic

Figure 2: Research Model (Path Coefficients and P-Values)

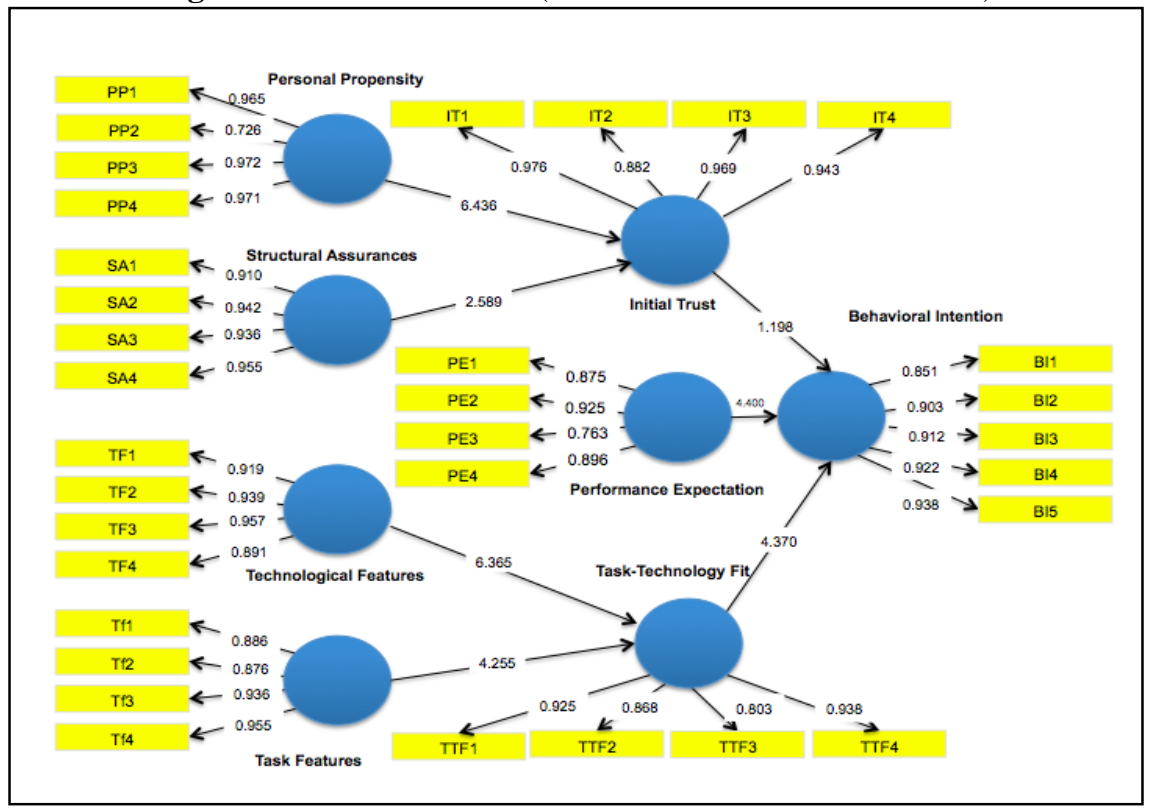




\subsubsection{Statistical Analysis and Hypotheses Testing}

Path $(\beta)$ and T-statistics were checked for relations between dependent and independent variables in this study. With PLS regression, we have found that six assumptions are significant in estimating the path relationships of each research pair between all seven paths. The bootstrapping was done to check the value of path coefficients in the internal model (number of iterations: 499). Figure 2 displays each relationship's route coefficient with the corresponding p-value. Greater t-values that 1.96 at 0.05 point is significant. Regarding UTAUT models, performance expectation (PE) was significantly positive for the BDA implementation of behavioral intent $(\mathrm{BI})(\beta=0.325, \mathrm{p}<0.05)$. Hypotheses 7 has therefore been supported. Findings on initial trust (IT) were also significantly positive for personal prosperity to trust (PPT) $(\beta=0.341, \mathrm{p}<0.05)$ and structural assurances $(\mathrm{SA})$ $(\beta=0.191 \mathrm{p}<0.05)$ of the IT Model, thereby supporting hypotheses 1 and 2 . TTF Model variables, technological feature $(\mathrm{TF})(\beta=0.419, \mathrm{p}<0.05)$ and task feature $(\mathrm{Tf})(\beta=0.251, \mathrm{p}<0.05)$, both of which were important antecedents for the task-fit technology (TTF), were supported. Last but not least, TTF was a significant BDA BI determinant $(\beta=0.291, p<0.05)$, supporting Hypothesis 6. However BI BDA was not affected by IT in government agencies as $(\beta=0.065, \mathrm{p}=0.263)$, hence Hypotheses 3 was rejected. All analyses are as illustrated in Table 4 and Figure 2.

Table 4: Significant Specific Indirect Effects

\begin{tabular}{|c|c|c|c|c|c|}
\hline & $\begin{array}{c}\text { Original } \\
\text { Sample } \\
(\mathrm{O})\end{array}$ & $\begin{array}{c}\text { Sample } \\
\text { Mean } \\
(\mathrm{M})\end{array}$ & $\begin{array}{c}\text { Standard } \\
\text { Deviation } \\
(\mathrm{STDEV})\end{array}$ & $\begin{array}{l}\text { T Statistics } \\
(|\mathrm{O} / \mathrm{STDEV}|)\end{array}$ & $\begin{array}{c}\mathrm{P} \\
\text { Values }\end{array}$ \\
\hline Initial Trust -> Behavioral Intention & 0.065 & 0.072 & 0.058 & 1.120 & 0.263 \\
\hline $\begin{array}{l}\text { Performance Expectation -> } \\
\text { Behavioral Intention }\end{array}$ & 0.325 & 0.326 & 0.078 & 4.138 & 0.000 \\
\hline Personal Propensity -> Initial Trust & 0.341 & 0.345 & 0.054 & 6.349 & 0.000 \\
\hline Structural Assurances -> Initial Trust & 0.191 & 0.194 & 0.071 & 2.687 & 0.007 \\
\hline Task Features -> Task-Technology Fit & 0.251 & 0.254 & 0.060 & 4.203 & 0.000 \\
\hline $\begin{array}{l}\text { Task-Technology Fit -> Behavioral } \\
\text { Intention }\end{array}$ & 0.291 & 0.288 & 0.071 & 4.077 & 0.000 \\
\hline $\begin{array}{l}\text { Technological Features -> Task- } \\
\text { Technology Fit }\end{array}$ & 0.419 & 0.419 & 0.065 & 6.414 & 0.000 \\
\hline
\end{tabular}

\section{RESULTS AND DISCUSSION}

The findings of the study showed two key determinant factors of behavioural intention to use BDA in Malaysian government agencies. The assumption that the technology is going to yield decent results raises the performance expectancy, as seen in past studies (Cabrera-Sánchez \& Villarejo-Ramos, 2019; Brunink, 2016; Chao, 2019; Queiroz, \& Farias, 2019) who found that expected results have significant positive effects on the intention to adopt BDA. This indicates perception of, as has been shown in previous studies, the implementation of BDA (better decision making, competitiveness, improve services, strategic planning, new innovation in services etc.) will achieve good results increases adoption (Lee \& Song, 2013; Yu, 2012). The respondents of the study expect BD to assist in advancing public demands for government services. They develop predictive models for 
innovative products and services by segmenting key features in service or product from the old and new testaments and by shaping the correlation between these characteristics and their business performance.

As shown by previous studies, technology task fit (TTF) has important consequences for the decision to use BDA (Bozan et al., 2016). The current study also analyzed TTF, with positive results on BDA adoption behavioral plans, showing that system characteristics should be compliant with the specific task of the user to effectively take up a BDA program. Furthermore, the findings which support previous studies (e.g. Shahbaz et al., 2019; Wang \& Lin, 2019; Khidzir et al., 2017; Zaini et al., 2020) proved that the task and technical characteristics will affect the fit of task technology, which decides the users' intention to implement BDA. The IT professionals in Malaysian government agencies intend to plan BDA because they anticipate that BDA technology fit is capable of integrating statistics, spatial analysis, semantics, digital learning and visualisation. Similarly, in order to make correlations and concrete observations, technology fit is required to evaluate models, compare various government data types and sources. Thus, it supports the study carried out by Feng et al. (2019) and Queiroz \& Farias (2019).

In view of these aims, this study highlighted effective outcomes and meaning for the practical implementation of the BDA frameworks and empirical directions (for future studies). This research focused on trust, because it was found to be of great concern to system users. However, trust does not affect the behavioral intention of implementing BD in government agencies, therefore it contradicts and is not consistent with previous studies (eg. Shahbaz et al. 2019; Queiroz \& Telles, 2018; Alalwan et al., 2017). It could be clarified that this discrepancy is due to the difficulty of the government agencies in Malaysia and its departments to protect the data privacy of the public. Hence, the agencies concerned must identify specific boundaries for the use of personal information. Moreover, when government agencies collect or manage public data, it is very challenging to comply with the legislation and other laws, which leads to doubt in the trust of BD. As MAMPU (2016) and OECD (2017) clearly mentioned, trusting data generation systems of public entities like Twitter and Facebook is difficult, as they have many machine-run undead accounts. Trust can be based on policy or integrity that can be accomplished by gathering, planning, processing, storing and communicating data. Furthermore, the findings for initial trust are important because it can be a potential barrier in the execution of BDA is underlined in the current study. The trust variable will act as a base for further studies and to gain deeper understanding of BDA study deployment.

Also, perhaps, the notion of 'trust' in BDA in government agencies in Malaysia is beyond data accuracy and security. Since trust is something intangible, it is difficult for IT professionals to focus on trust and believe that it will become a less relevant factor in value proposition of data and analytics. Thus, it is something unmanageable that will make them move forward with less confidence, affects their decision making and their customer relationships. This finding shows that more focus on the determinants of initial trust in big data and other technology implementation in government agencies is necessary.

The research has also shown a detrimental effect of technological features and task features on the technology task fit in government agencies. We can therefore say that the findings correspond to all hypotheses of Klopping and McKinney (2004) who used a hybrid approach that merged TTF and TA models to test e-commerce adoption (Klopping \& McKinney, 2004). The use of mobile 
banking was studied by Zhou et al. (2010) utilizing an adaptive TTF paradigm and the common philosophy of application adoption and usage (Zhou et al., 2010). The characteristics of BDA are advanced analytics that include complicated functions with features such as estimation methods, data mining and, if any, high-power analytics systems. Thus, this feature can directly support TTF in government agencies as the Malaysian government is serious about investing in technology facilities.

To secure the infrastructure and the way it provides services, a personal trend to trust BD providers and products is necessary. The key objective is to ensure the confidentiality, completeness, and quality of BD protection. BD collected in the cloud from a number of sources including the IoT (Internet of Things) has a number of personal views on physical and logical security. Cloud storage should be protected because the user information risks insider attacks, cyber fraud and unsafe access. Personal confidence can therefore affect confidence in BDA management.

Structural assurances are collected and processed in the increased volume of data produced, which must be relying on the source and methods to collect them over the entire life cycle. Trust considerations about collection, organisation, access and analysis of data are also expressed (MAMPU, 2016). BD needs to examine the structure of authenticity and credibility when considering a professional IT's perspective of the trust in large data, whether to store, socialize, buy, sell or transact information, as it can be gathered from profitable commercial organizations, which are business-oriented platforms, and to check the validity of and legitimacy of the data gathered. Personal inclination of BDA can affect confidence, reputation and communication of data through collection, supply, data calculation and storage.

\subsection{Contribution of the Study}

The findings of the study have many consequences for the current body of knowledge in the fields of study of government services and technology. This work examined the factors influencing the propensity of government agencies to use the BDA by using TTF, UTAUT, and initial ITM. Based on the findings, it can be understood that BDA is starting to be utilized by the respondents, and this trend is favorable. The personal willingness to trust is therefore successful. Moreover, BDA provides safe access to data and reduces operating risks and minimizes decision errors in managing organisation. Individuals are also not at risk in their decision making, planning and predicting.

The framework provides useful insights into the broad range of variables affecting big data acceptance for academics and IT practitioners. While certain factors have previously been evaluated in other technological breakthrough models in our model, in the sense of big data acceptance, this research poses novel factors. An example is data services that in other IT adoption studies have not been listed. In this analysis, though, it is an important consideration because of the unique characteristics of big data. Similarly, big data protection and security problems make policies and regulations another significant consideration in.

In most previous research, the advantages, consequences and opportunities for BDA were only highlighted because BDA is at the early adoption and a relatively new subject. Several scholars studied BDA and the latest studies focused on a certain viewpoint or simply highlighted TAM, UTAUT, TFF, and ITM theory separately. This is the first BDA study to propose a model combining UTAUT, TTF and ITM theories as a predictor probably of compartmental intentions to 
use BDA. Therefore, convergence and application of all these BDA adoption ideas add new insights to the existing literature. The model of this study is helpful and promotes a theory for further BDA research. By utilizing the model, existing public agencies can know their own BDA capability, centred around activities with specifically tailored outcomes, organization dynamics, resources, skills and potential services. Government agencies can identify, within their own organizations, the most common inhibitors to constructing and implementing an effective BDA and plan to mitigate these accordingly.

The study has also made various practical contributions. The findings suggest significant recommendations and consequences for BDA systems practitioners and application developers, which could coincide with the successful implementation of BDA systems. Connecting BDA system functions and technology features to the necessary tasks is critical. It is the same for system performance expectancy. Such strategy will yield more effective outcomes for practitioners when implementing BDA systems. This research gives practitioners an initial way to incorporate and endorse BDA activities in their organizations in order to optimize the benefits of revolutionary technology, in particular in public agencies. Top management or business managers in government departments are expected to have reasonable expectations of the efficiency of big data along with its incorporation problems for successful implementation of BDA solutions. Managers who oversee BDA adoption programs are expected to assemble a team of experts whose expertise span conventional platforms and ecosystems for analytics.

\subsection{Limitations and Future Research}

This research inherits many restrictions that cannot be met because of many resource constraints. This research focuses on factors influencing IT professionals' tendency to use BDA within government agencies using the Initial Trust Model, Unified Theory of Acceptance and Use of Technology (UTAUT), and the Task Technology Fit model. It was found that IT professionals are still aware that there is a tendency to use BDA technology in their day-to-day tasks such as decision making, planning, identifying problems and needs of the community, and this tendency is well established. Therefore, the tendency to believe is in the early belief category. Avenues for potential investigation have been established by the philosophical structure and quantitative design of this study. In the study concerning the adoption of technologies, as individual human influences become more evident, having proven models and structures to be implemented in various environments enables researchers to draw on this and related studies more effectively. in other areas including personality characteristics and adoption of technologies can also offer ample avenues of legitimate research. Related studies using this approach to evaluate and verify the effect of trust, technology fits and benefit expectation on the implementation of emerging technologies should also be considered.

This research also focuses on investigating the intention of the user to embrace BDA, which completely neglects the implementation of the system. Future researchers could therefore identify the intentions of the developers/architects in developing and implementing BDA systems. Finally, the research is focused on cross-sectional settings that reduce the calculation of the accuracy of respondent actions and the study needs to be conducted in a longitudinal setup to eliminate this discrepancy and to greatly add to the information. 


\section{CONCLUSION}

While big data adoption can offer many government advantages, organizations can consider and address the complexities of big data adoption before it can bring value to their programs. The method of implementation of big data consists of several interrelated variables that may influence the activities of agencies. The optimal use of big data within organisations can be facilitated by knowing these variables explicitly. Therefore, the production and application of big data requires a systematic structure.

The need to control government data and activities in real time also makes the task features fit into the task technology. With BDA, policy programs can be enforced and funded. Therefore, tasktechnology adaptation is effective for the behavior of the users. Finally, the limited number of skilled IT practitioners with required BDA and IT skills has brought about the attractiveness of BDA to facilitate analysis by reducing workforce costs and automating the processes. Despite the time and skills of BD using analytics, success expectations have had a positive influence on the conduct of users.

Additionally, in this study BDA provides the ability to process information securely and reduce operational risks and labor shortages. Individuals do not risk making decisions and the work processes become more efficient and structured. Therefore, IT professionals may recognize that structural assurance affects their initial trust. Computer processing power is required to understand and view patterns in the data to assist in decision making and problem solving. The process and data analysis performed on this network is safe and reliable. Based on the findings, this new trust model should be tested to measure the significant impact on the intentions of the respondents.

\section{AKNOWLEDGEMENT}

This research is supported by MOHE under the Fundamental Research Grant Scheme (FRGS) with project code: 600-IRMI/FRGS 5/3 (079/2019)

\section{REFERENCES}

Abbasi, A., Sarker, S., \& Chiang, R. H. L. (2016). Big Data Research in Information Systems: Toward an Inclusive Research Agenda. Journal of the Association for Information Systems, 17(2), 3. https://doi.org/10.17705/1jais.00423

Abbas Naqvi, M. H., Jiang, Y., Miao, M., \& Naqvi, M. H. (2020). The effect of social influence, trust, and entertainment value on social media use: Evidence from Pakistan. Cogent Business \& Management, 7(1), 1723825. https://doi.org.10.1080/23311975.2020.1723825

Abouelmehdi, K., Beni-Hessane, A., \& Khaloufi, H. (2018). Big healthcare data: preserving security and privacy. Journal of Big Data, 5(1), 1-18.

Adair, B. (2019). Features of Big Data Analytics and Requirements. SelectHub. https://www.selecthub.com/big-data-analytics/big-data-analytics-requirements/

Alalwan, A. A., Dwivedi, Y. K., \& Rana, N. P. (2017). Factors influencing adoption of mobile banking by Jordanian bank customers: Extending UTAUT2 with trust. International 
Journal of Information $\quad$ Management, 37(3), https://doi:10.1016/j.ijinfomgt.2017.01.002

Alarcon, G. M., Lyons, J. B., \& Christensen, J. C. (2016). The effect of propensity to trust and familiarity on perceptions of trustworthiness over time. Personality and Individual Differences, 94, 309-315. https://doi.org/10.1016/j.paid.2016.01.031

Alcácera, V., \& Cruz-Machado, V. (2019). Scanning the Industry 4.0: A Literature Review on Technologies for Manufacturing Systems. Engineering Science and Technology, an International Journal, 22(3), 899-919.

Al-Shiakhli, S. (2019). Big data analytics: a literature review perspective (Unpublished Master's Thesis). The Luleå University of Technology.

Ballantyne, A., \& Stewart, C. (2019). Big data and public-private partnerships in healthcare and research. Asian Bioethics Review, 11(3), 315-326. https://doi.org/10.1007/s41649-01900100-7

Bahari, B. (2016, September 19). Malaysia on Track to Become Southeast Asian Hub on Big Data \& Analytics. New Straits Times. http://www.nst.com.my/news/2016/09/174270/malaysiatrack-become-southeast-asian-hub-bigdata-analytics

Behl, A., Dutta, P., Lessmann, S., Dwivedi, Y. K., \& Kar, S. (2019). A conceptual framework for the adoption of big data analytics by e-commerce startups: a case-based approach. Information Systems and e-Business Management, 17(2), 285-318.

Bere, A. (2018). Applying an extended task-technology fit for establishing determinants of mobile learning: an instant messaging initiative. Journal of Information Systems Education, 29(4), 239-252.

Bibri, S. E., \& Krogstie, J. (2017). The core enabling technologies of big data analytics and contextaware computing for smart sustainable cities: a review and synthesis. Journal of Big Data, 4(1), 1-50. https://doi.org/10.1186/s40537-017-0091-6

Bolonne, H., \& Wijewardene, P. (2020). Critical Factors Affecting the Intention to Adopt Big Data Analytics in Apparel Sector, Sri Lanka. https://dx.doi.org/10.14569/IJACSA.2020.0110620

Bozan, K., Parker, K., \& Davey, B. (2016, January 5-8). A closer look at the social influence construct in the UTAUT Model: An institutional theory based approach to investigate health IT adoption patterns of the elderly. In the Proceedings of 2016 49th Hawaii International Conference on System Sciences (HICSS) (pp. 3105-3114). USA, Koala.

Brock, V., \& Khan, H. U. (2017). Big data analytics: does organizational factor matters impact technology acceptance?. Journal of Big Data, 4(1), 1-28.

Brünink, L. (2016). Cross-functional Big Data integration: Applying the UTAUT model. University of Twente (The Netherlands).

Cabrera-Sánchez, J. P., \& Villarejo-Ramos, Á. F. (2019). Fatores que afetam a adoção de análises de Big Data em empresas. Revista de Administração de Empresas, 59, 415-429. https://doi.org/10.1590/s0034-759020190607

Cao, Q., \& Niu, X. (2019). Integrating context-awareness and UTAUT to explain Alipay user adoption. International Journal of Industrial Ergonomics, 69, 9-13.

Chao, C. M. (2019). Factors determining the behavioral intention to use mobile learning: An application and extension of the UTAUT model. Frontiers in psychology, 10, 1652. https://doi.org.10.3389/fpsyg.2019.01652

D'Ambra, J., Wilson, C. S., \& Akter, S. (2013). Application of the task-technology fit model to structure and evaluate the adoption of E-books by Academics. Journal of the American society for information science and technology, 64(1), 48-64. 
Debussche, J., César, J. \& Moortel, I. D. (2019, April). Big Data \& Issues \& Opportunities: Discrimination. Bird \& Bird. https://www.twobirds.com/en/news/articles/2019/global/bigdata-and-issues-and-opportunities-discrimination

Desjardins, J. (2017). The 100 websites that rule the internet. Visual Capitalist. www.visualcapitalist.com

Elragal, A., \& Klischewski, R. (2017). Theory-driven or process-driven prediction? Epistemological challenges of big data analytics. Journal of Big Data,4(1), 1-20. https://doi.org/10.1186/s40537-017-0079-2

Erevelles, S., Fukawa, N., \& Swayne, L. (2016). Big Data consumer analytics and the transformation of marketing. Journal of business research, 69(2), 897-904.

Falahat, M., Lee, Y. Y., Foo, Y. C., \& Chia, C. E. (2019). A model for consumer trust in ecommerce. Asian Academy of Management Journal, 24(2), 93-109. https://doi.org/10.21315/aamj2019.24.s2.7

Feng, M., Zheng, J., Ren, J., Hussain, A., Li, X., Xi, Y., \& Liu, Q. (2019). Big data analytics and mining for effective visualization and trends forecasting of crime data. IEEE Access, 7 , 106111-106123.

Fornell, C., \& Larcker, D. F. (1981). Evaluating structural equation models with unobservable variables and measurement error. Journal of marketing research,18(1), 39-50. http://dx.doi.org/10.2307/3151312.

Galetto, M. (2018, March 8). What is Business Analytics? NGDATA. https://www.ngdata.com/ what-is-business-analytics/

Gao, L., \& Waechter, K. A. (2017). Examining the role of initial trust in user adoption of mobile payment services: an empirical investigation. Information Systems Frontiers, 19(3), 525548. https://doi.org/10.1007/s10796-015-9611-0

Giest, S. (2017). Big Data for Policymaking: Fad or Fasttrack? Policy Sciences, 50(3), 367-382.

Gong, Z., Han, Z., Li, X., Yu, C., \& Reinhardt, J. D. (2019). Factors influencing the adoption of online health consultation services: the role of subjective norm, trust, perceived benefit, and offline habit. Frontiers in public health, 7, 286. https://doi.org.10.3389/fpubh.2019.00286

Goodhue, D. L., \& Thompson, R. L. (1995). Task-technology fit and individual performance. MIS quarterly, 213-236.

Günther, W. A., Mehrizi, M. H. R., Huysman, M., \& Feldberg, F. (2017). Debating big data: A literature review on realizing value from big data. The Journal of Strategic Information Systems, 26(3), 191-209. https://doi.org/10.1016/j.jsis.2017.07.003

Hair, J. F., Black, W. C., Babin, B. J., Anderson, R. E., \& Tatham, R. L. (2006). Multivariate data analysis $\left(6^{\text {th }}\right.$ ed). Upper Saddle River, NJ: Pearson Prentice Hall.

Hair, J. F., Black, W. C., Babin, B. J., \& Anderson, R. E. (2010). Multivariate Data Analysis (7 $^{\text {th }}$ ed). Prentice Hall, Upper Saddle River, New Jersey.

Hair, J. F., Sarstedt, M., Hopkins, L., \& Kuppelwieser, V. G. (2014). Partial Least Squares Structural Equation Modeling (PLS-SEM): An Emerging Tool for Business Research. European Business Review, 26, 106-121. https://doi.org.10.1108/EBR-10-2013-0128

Hasan, M. M., Popp, J., \& Oláh, J. (2020). Current landscape and influence of big data on finance. Journal of Big Data, 7(1), 1-17. https://doi.org/10.1186/s40537-020-00291-z

Heidari, H., Moosakhani, M., Alborzi, M., Divandari, A., \& Radfar, R. (2018). Investigating the Effective Factors on the Customers' Behavioral propensity to Use Blockchain Capabilities as financial instrument. Journal of Money and Economy, 13(2), 195-219. http://jme.mbri.ac.ir/article-1-423-en.html 
Ingrams, A. (2019). Public values in the age of big data: A public information perspective. Policy \& Internet, 11(2), 128-148.

International Telecommunication Union. (ITU) (2018). Big data, machine learning, consumer protection and privacy. Report of Trust Workstream. Geneva, Switzerland. https://www.itu.int/en/ITU-T/extcoop/figisymposium/Documents/FIGI_SIT_Techinical \%20report_Big\%20data\%2C\%20Machine\%20learning\%2C\%20Consumer\%20protection $\% 20$ and\%20Privacy_f.pdf

Jibril, A. B., Kwarteng, M. A., Chovancova, M., \& Pilik, M. (2019). The impact of social media on consumer-brand loyalty: A mediating role of online based-brand community. Cogent Business \& Management, 6(1), 1-19. https://doi.org/10.1080/23311975.2019.1673640

Kaabachi, S., Mrad, S. B., \& O’Leary, B. (2019). Consumer's initial trust formation in IOB's acceptance: The role of social influence and perceived compatibility. International Journal of Bank Marketing, 37(2), 507-530.

Kennedy, H., Moss, G., Birchall, C., \& Moshonas, S. (2015). Balancing the potential and problems of digital methods through action research: Methodological reflections. Information, Communication \& Society, 18(2), 172-186.

Khan, N., Yaqoob, I., Hashem, I. A., Inayat, Z., Ali, W. K., Alam, M., Shiraz, M., \& Gani, A. (2014). Big data: survey, technologies, opportunities, and challenges. The Scientific World Journal, 712826. https://doi.org/10.1155/2014/712826

Kim, K. K., \& Prabhakar, B. (2004). Initial trust and the adoption of B2C e-commerce: The case of internet banking. ACM SIGMIS Database: the DATABASE for Advances in Information Systems, 35(2), 50-64. https://doi.org/10.1145/1007965.1007970

Kim, E. S., Choi, Y., \& Byun, J. (2020). Big Data Analytics in Government: Improving Decision Making for R\&D Investment in Korean SMEs. Sustainability, 12(1), 202.

Klopping, I. M., \& McKinney, E. (2004). Extending the technology acceptance model and the task-technology fit model to consumer e-commerce. Information Technology, Learning, and Performance Journal, 22(1), 35-48.

Koufaris, M., \& Hampton-Sosa, W. (2004). The development of initial trust in an online company by new customers. Information \& management, 41(3), 377-397.

KPMG (2016). Building trust in analytics. https://home.kpmg.com/xx/en/home/insights/2016/10/building-trust-in-analytics.html

Kubina, M., Varmus, M., \& Kubinova, I. (2015). Use of big data for competitive advantage of company. Procedia Economics and Finance, 26, 561-565. https://doi.org/10.1016/S2212 5671(15)00955-7

Kurt, Ö. E., \& Tingöy, Ö. (2017). The acceptance and use of a virtual learning environment in higher education: an empirical study in Turkey, and the UK. International Journal of Educational Technology in Higher Education, 14(1), 1-15. https://doi.org/10.1186/s41239017-0064-Z

Lai, Y., Sun, H., \& Ren, J. (2018). Understanding the determinants of big data analytics (BDA) adoption in logistics and supply chain management: An empirical investigation. International Journal of Logistics Management, 29(2), 676-703.

Latif, Z., Tunio, M. Z., Pathan, Z. H., Jianqiu, Z., Ximei, L., \& Sadozai, S. K. (2018, March). A review of policies concerning development of big data industry in Pakistan: Subtitle: Development of big data industry in Pakistan. In Proceedings of 2018 International Conference on Computing, Mathematics and Engineering Technologies (iCoMET) (pp. 15). IEEE. 
Laugesen, J., \& Hassanein, K. (2017). Adoption of personal health records by chronic disease patients: A research model and an empirical study. Computers in Human Behavior, 66, 256272.

Lee, C. -C., Cheng, H. K., \& Cheng, H.-H. (2007). An empirical study of mobile commerce in insurance industry: Task-technology fit and individual differences. Decision Support Systems, 43(1), 95-110.

Lee, J.-H., \& Song, C.-H. (2013). Effects of trust and perceived risk on user acceptance of a new technology service. Social Behaviour and. Personality an International Journal, 41(4), 587-597. https://doi.org.10.2224/sbp.2013.41.4.587

Lehrer, C., Wieneke, A., Vom Brocke, J. A. N., Jung, R., \& Seidel, S. (2018). How big data analytics enables service innovation: materiality, affordance, and the individualization of service. Journal of Management Information Systems, 35(2), 424-460.

Lewicki, R. J., \& Bunker, B. B. (1996). Developing and maintaining trust in working relationships. In R. M. Kramer \& T. R. Tyler (Eds.), Trust in organizations. Frontiers of theory and research. Thousand Oaks: Sage Publications.

Liebenberg, J., Benade, T., \& Ellis, S. (2018). Acceptance of ICT: Applicability of the unified theory of acceptance and use of technology (UTAUT) to South African Students. The African Journal of Information Systems, 10(3), 1.

Lin, W. R., Wang, Y. H., \& Hung, Y. M. (2020). Analyzing the factors influencing adoption intention of internet banking: Applying DEMATEL-ANP-SEM approach. Plos one, 15(2), e0227852. https://doi.org/10.1371/journal.pone.0227852

Löfgren, K., \& Webster, C. W. R. (2020). The value of Big Data in government: The case of 'smart cities.' Big Data \& Society, 7(1), 1-14. https://doi.org/10.1177/2053951720912775

Longo, J., \& McNutt, K. (2018). From Policy Analysis to Policy Analytics. Policy Analysis in Canada, 367-389. https://doi.org.10.1332/policypress/9781447334910.003.0018

Mahfuz, M. A., Khanam, L., \& Hu, W. (2016, September). The influence of culture on m-banking technology adoption: An integrative approach of UTAUT2 and ITM. In 2016 Portland International Conference on Management of Engineering and Technology (PICMET) (pp. 824-835). IEEE. https://doi.org.10.1109/PICMET.2016.7806814

MAMPU (2014). National Big Data Analytics Initiative. http://tinyurl.com/z3ffgdt.

MAMPU (2016). Analitis Data Raya Sektor Awam (DRSA). http://www.mampu.gov.my/ms/data raya-sektor-awam-drsa

Maroufkhani, P., Wan Ismail, W.K. \& Ghobakhloo, M. (2020). Big data analytics adoption model for small and medium enterprises. Journal of Science and Technology Policy Management, 11(4), 483-513. https://doi.org/10.1108/JSTPM-02-2020-0018

Mayer, R. C., \& Davis, J. H. (1999). The effect of the performance appraisal system on trust for management: A field quasi-experiment. Journal of Applied Psychology, 84(1), 123-136. https://doi.org/10.1037/0021-9010.84.1.123

McCole, P., Ramsey, E., Kincaid, A., Fang, Y., \& Li, H. (2019). The role of structural assurance on previous satisfaction, trust and continuance intention: The case of online betting. Information Technology and People, 32(4), 781-801. https://doi.org/10.1108/ITP-08-20170274

McFarland, D. A., \& McFarland, H. R. (2015). Big Data and the danger of being precisely inaccurate. Big Data and Society, 2(2), 1-4.

McKnight, D. H., \& Chervany, N. L. (2006). Reflections on an initial trust-building model. In Handbook of Trust Research (pp. 29-51). Edward Elgar Publishing. https://doi.org/10.4337/9781847202819.00008 
Mikalef, P., Boura, M., Lekakos, G., \& Krogstie, J. (2019). Big data analytics and firm performance: Findings from a mixed-method approach. Journal of Business Research, 98, 261-276.

Mikalef, P., Pappas, I. O., Krogstie, J., \& Giannakos, M. (2018). Big data analytics capabilities: A systematic literature review and research agenda. Information Systems and e-Business Management, 16(3), 547-578.

Mithas, S., Tafti, A., Bardhan, I., \& Goh, J. M. (2012). Information technology and firm profitability: mechanisms and empirical evidence. Mis Quarterly, 36(1), 205-224. https://doi.org/10.2307/41410414

Moore, G.C., \& Benbasat, I. (1991). Development of an Instrument to Measure the Perceptions of Adopting an Information Technology Innovation. Information Systems Research, 2(3), 192222.

Munné, R. (2016). Big data in the public sector. In New Horizons for a Data-Driven Economy (pp. 195-208). Springer, Cham.

Nantais, J. (2019). Data Science for Government Performance. Towards Data Science. https://towardsdatascience.com/@joelnantais

Ngampornchai, A., \& Adams, J. (2016). Students' acceptance and readiness for E-learning in Northeastern Thailand. International Journal of Educational Technology in Higher Education, 13(1), 1-13. https://doi.org/10.1186/s41239-016-0034-x

Khidzir, N. Z., Wan Abdul Ghani, W. S. D., Tan, T. G. (2017). Cloud-Based Mobile-Retail Application for Textile Cyberpreneurs: Task-Technology Fit Perspective Analysis. In Proceedings of the International Conference on High Performance Compilation, Computing and Communications (HP3C-2017). Association for Computing Machinery, New York, NY, USA, 65-70. https://doi.org/10.1145/3069593.3069609

O'Connor, Y., Andreev, P., \& O'Reilly, P. (2020). MHealth and perceived quality of care delivery: a conceptual model and validation. BMC medical informatics and decision making, 20(1),113. https://doi.org/10.1186/s12911-020-1049-8

OECD (2018). Digital Government Review of Colombia: Towards a Citizen-Driven Public Sector, OECD Digital Government Studies, OECD Publishing, Paris. https://dx.doi.org/10.1787/9789264291867-en

OECD (2017). OECD Digital Economy Outlook 2017, OECD Publishing, Paris, https://dx.doi.org/10.1787/9789264276284-en.

Okello, D. R., \& Gilson, L. (2015). Exploring the influence of trust relationships on motivation in the health sector: a systematic review. Human resources for health, 13(1), 1-18. https://doi.org/10.1186/s12960-015-0007-5

Oliveira, T., Faria, M., Thomas, M.A. and Popovič, A. (2014). Extending the understanding of mobile banking adoption: When UTAUT meets TTF and ITM. International Journal of Information Management, 34(5), 689-703.

Omotayo, F. O., \& Haliru, A. (2020). Perception of task-technology fit of digital library among undergraduates in selected universities in Nigeria. The Journal of Academic Librarianship, 46(1), 102097.

Paramasivam, S. (2016, May 11). 85\% of Malaysian Businesses Feel the Need For a Modern Data Culture - Yet 44\% Have a Limited Digital Strategy in Place. Microsoft Malaysia News Center. https://news.microsoft.com/en-my/2016/05/11/85-malaysian-businesses-feel-needmodern-data culture-yet-44-limited-digital-strategy-place/\#_ftn1. 
Pencheva, I., Esteve, M., \& Mikhaylov, S. J. (2020). Big Data and AI - A transformational shift for government: So, what next for research? Public Policy and Administration, 35(1), 24 44. https://doi.org/10.1177/0952076718780537

Queiroz, M. M., \& Farias, S. C. (2019). Intention to adopt big data in supply chain management: A Brazilian perspective. RAE-Revista de Administração de Empresas, 59(6), 389-401. http://dx.doi.org/10.1590/S0034-759020190605

Queiroz, M. M., \& Wamba, S. F. (2019). Blockchain adoption challenges in supply chain: An empirical investigation of the main drivers in India and the USA. International Journal of Information Management, 46, 70-82. https://doi.org.10.1016/j.ijinfomgt.2018.11.021

Queiroz, M. M., \& Telles, R. (2018). Big data analytics in supply chain and logistics: an empirical approach, The International Journal of Logistics Management, 29(2), 767-783. https://doi.org/10.1108/IJLM-05-2017-0116

Rai, R. S., \& Selnes, F. (2019). Conceptualizing task-technology fit and the effect on adoption-a case study of a digital textbook service. Information \& Management, 56(8), 103161.

Raja Mohd Ali, R. H., Mohamad, R., \& Sudin, S. (2016). A proposed framework of big data readiness in public sectors. AIP Conference Proceedings, 1761, 020089. https://doi.org/10.1063/1.4960929

Rialti, R. \& Zollo, L., Ferraris, A. \& Alon, I. (2019). Big data analytics capabilities and performance: Evidence from a moderated multi-mediation model. Technological Forecasting and Social Change, 149, 119781.

Said, G. R. E. (2015). Understanding knowledge management system antecedents of performance impact: Extending the task-technology fit model with intention to share knowledge $\begin{array}{lllll}\text { construct. } & \text { Future } & \text { Business } & \text { Journal, } & \text { 1(1-2), }\end{array}$ https://doi.org/10.1016/j.fbj.2015.11.003

Sam, K. M., \& Chatwin, C. R. (2018). Understanding Adoption of Big Data Analytics in China: From Organizational Users Perspective. 2018 IEEE International Conference on Industrial Engineering and Engineering Management (IEEM), 507-510. https://doi.org.10.1109/IEEM.2018.8607652

Sbaffi, L., \& Rowley, J. (2017). Trust and Credibility in Web-Based Health Information: A Review and Agenda for Future Research. Journal of Medical Internet Research, 19(6), e218. https://doi.org.10.2196/jmir.7579

Schindler, L. A., Burkholder, G. J., Morad, O. A., \& Marsh, C. (2017). Computer-based technology and student engagement: a critical review of the literature. International journal of educational technology in higher education, 14(1), 1-28. https://doi.org/10.1186/s41239017-0063-0

Schintler, L. A., \& Kulkarni, R. (2014). Big Data for Policy Analysis: The Good, the Bad, and the Ugly. Review of Policy Research, 31(4), 343-348. https://doi.org.10.1111/ropr.12079

Schneider, J., Handali, J. P., \& vom Brocke, J. (2018, June). Increasing trust in (big) data analytics. In R. Matulevicius \& R. Dijkman (Eds.), International Conference on Advanced Information Systems Engineering (pp. 70-84). Springer, Cham.

Schüll, A., \& Maslan, N. (2018). On the Adoption of Big Data Analytics: Interdependencies of Contextual Factors. In the Proceedings of the $20^{\text {th }}$ International Conference on Enterprise Information Systems (ICEIS 2018) (pp. 425-431). SCITEPRESS - Science and Technology Publications, Lda.

Shahbaz, M., Gao, C., Zhai, L., Shahzad, F., \& Hu, Y. (2019). Investigating the adoption of big data analytics in healthcare: the moderating role of resistance to change. Journal of Big Data, 6(6), 1-20. https://doi.org/10.1186/s40537-019-0170-y 
Shahbaz, M., Gao, C., Zhai, L., Shahzad, F., Abbas, A., \& Zahid, R. (2020). Investigating the Impact of Big Data Analytics on Perceived Sales Performance: The Mediating Role of Customer Relationship Management Capabilities. Complexity, 2020, 1-17. https://doi.org.10.1155/2020/5186870

Sivarajah, U., Kamal, M. M., Irani, Z., \& Weerakkody, V. (2017). Critical analysis of big data challenges and analytical methods. Journal of Business Research, 70, 263-286.

Smithson, M. (2018). Trusted Autonomy Under Uncertainty. In H. A. Abbass, J. Scholz, D. J. Reid (Eds.), Foundations of Trusted Autonomy. Studies in Systems, Decision and Control (pp. 185-201). Springer, Cham.

Spies, R., Grobbelaar, S., \& Botha, A. (2020). A Scoping Review of the Application of the TaskTechnology Fit Theory. Responsible Design, Implementation and Use of Information and Communication Technology, 12066, 397-408. Springer, Cham.

Stedman, C. (2017). Eyeing the future with predictive analytics can pay dividends now. http://searchbusinessanalytics.techtarget.com/ehandbook/Predictive-data-analyticsadvances-businesses-ahead-of-the-game

Tam, C. \& Oliveira, T. (2016). Understanding the impact of m-banking on individual performance: DeLone \& McLean and TTF perspective. Computers in Human Behavior, 61, 233-244. https://doi.org.10.1016/j.chb.2016.03.016.

Talwar, S., Dhir, A., Kaur, P., \& Mantymaki, M. (2020). Why do people purchase from online travel agencies (OTAs)? A consumption values perspective. International Journal of Hospitality Management, 88, 102534. https://doi.org.10.1016/j.ijhm.2020.102534

The Multimedia Development Corporation. (MDeC) (2016). MDeC To Make Malaysia Regional Hub for Big Data Analytics. http://smeam.gomalaysia.com.my/en/news/27010

Uddin, M. A., Alam, M. S., Mamun, A. A., Khan, T. U. Z., \& Akter, A. (2020). A study of the adoption and implementation of enterprise resource planning (ERP): Identification of moderators and mediator. Journal of Open Innovation: Technology, Market, and Complexity, 6(1), 1-18.

UNESCO (2017). The Data Revolution in Education. Montreal: UNESCO Institute for Statistics. https://doi.org/10.15220/978-92-9189-213-6-en

Venkatesh, V., \& Davis, F. (2000). A Theoretical Extension of the Technology Acceptance Model: Four Longitudinal Field Studies. Management Science, 46, 186-204. https://doi.org.10.1287/mnsc.46.2.186.11926

Venkatesh, V., Morris, M., Davis, G., \& Davis, F. (2003). User Acceptance of Information Technology: Toward a Unified View. MIS Quarterly, 27(3), 425-478. https://doi.org.10.2307/30036540

Verma, S., \& Chaurasia, S. (2019). Understanding the determinants of big data analytics adoption. Information Resources Management Journal, 32(3), 1-26.

Vitari, C., \& Raguseo, E. (2020). Big data analytics business value and firm performance: linking with environmental context. International Journal of Production Research, 58(18), 54565476.

Vongjaturapat, S. (2018). Application of the Task-Technology Fit Model to Structure and Evaluation of the Adoption of Smartphones for Online Library Systems. Science \& Technology Asia, 23(1), 39-56. https://ph02.tci-thaijo.org/index.php/SciTechAsia/article/ view/124831

Wahab, S. N., Olugu, E. U., Lee, W. C., \& Tan, S. Y. (2018, November 15-16). Big data analytics adoption in Malaysia warehousing industry. The 32nd International Business Information Management Association Conference (IBIMA) (pp. 2349-2365). Seville, Spain. 
Walker, R., \& Brown, I. (2019). Big data analytics adoption: A case study in a large South African telecommunications organisation. South African Journal of Information Management, 21(1), 1-10. https://doi.org/10.4102/sajim.v21i1.1079

Wang, S. J., \& Moriarty, P. (2018). Barriers to the Implementation of Big Data. In Big Data for Urban Sustainability (pp. 65-80). Springer, Cham.

Wang, S. L., \& Lin, H. I. (2019). Integrating TTF and IDT to evaluate user intention of big data analytics in mobile cloud healthcare system. Behaviour \& Information Technology, 38(9), 974-985.

Wayne, M. (2018). Assessment of Factors Influencing Intent-to-Use Big Data Analytics in an Organization: A Survey Study. [Doctoral dissertation, Nova Southeastern University]. NSUWorks. https://nsuworks.nova.edu/gscis_etd/1054/

Alabdallat, W. I. M. (2020). Toward a mandatory public e-services in Jordan. Cogent Business \& Management, 7(1), 1727620. https://doi.org.10.1080/23311975.2020.1727620

Woolley, J. P. (2019). Trust and Justice in Big Data Analytics: Bringing the Philosophical Literature on Trust to Bear on the Ethics of Consent. Philosophy \& Technology, 32(1), 111134. https://doi.org/10.1007/s13347-017-0288-9

World Bank Group. (2017). The Malaysia Development Experience Series: Open Data Readiness Assesment. https://documents1.worldbank.org/curated/en/529011495523087262/pdf/ 115192-WP-PUBLIC-MALAYSIA-DEVELOPMENT-EXPERIENCE-SERIES.pdf

Wu, B., \& Chen, X. (2017) Continuance Intention to Use MOOCs: Integrating the Technology Acceptance Model (TAM) and Task Technology Fit (TTF) Model. Computers in Human Behavior, 67, 221-232. https://doi.org/10.1016/j.chb.2016.10.028

Yang, H. H., Feng, L., \& MacLeod, J. (2019). Understanding College Students' Acceptance of Cloud Classrooms in Flipped Instruction: Integrating UTAUT and Connected Classroom Climate. Journal of Educational Computing Research, 56(8), 1258-1276. https://doi.org/10.1177/0735633117746084

Yoo, S. K., \& Kim, B. Y. (2019). The effective factors of cloud computing adoption success in organization, Journal of Asia Finance, Economics and Business, 6(1), 215-227.

Yu, S. \& Lee, J. (2019). The effects of consumers' perceived values on intention to purchase upcycled products. Sustainability, 11, 1034.

$\mathrm{Yu}, \mathrm{C} .-\mathrm{S} .$, (2012). Factors affecting individuals to adopt mobile banking: empirical evidence from the UTAUT model. Journal of Electronic Commerce Research, 13(2), 104-121.

Yunus, Y. (2018, November). Harnessing Data Science for Data Driven Public Service Delivery. 6th Malaysia Statistics Conference, Kuala Lumpur, Malaysia.

Zaini, M. K., Masrek, M. N., Abdullah Sani, M. K. J. (2020). The impact of information security management practices on organisational agility. Information and Computer Security, 28(5), 681-700.

Zhou, T. (2013). An empirical examination of continuance intention of mobile payment services. Decision Support Systems, 54(2), 1085-1091.

Zhou, T., Lu, Y., \& Wang, B. (2010). Integrating TTF and UTAUT to explain mobile banking user

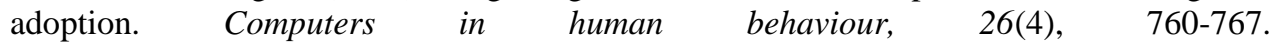
https://doi.org/10.1016/i.chb.2010.01.013

Zhuang, Y., Wu, F., Chen, C., \& Pan, Y. (2017). Challenges and opportunities: from big data to knowledge in AI 2.0. Frontiers of Information Technology \& Electronic Engineering, 18(1) 3 - 14. https://doi.org/10.1631/FITEE.1601883 